\title{
A systematic review and meta-analysis of the role of sugar-free chewing gum on Streptococcus mutans
}

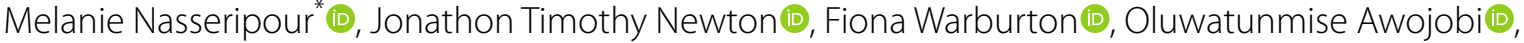 \\ Sonya Di Giorgio (D), Jennifer Elizabeth Gallagher (1) and Avijit Banerjee(1)
}

\begin{abstract}
Background: Preventive strategies targeting Streptococcus mutans may be effective in reducing the global burden of caries. The aim of the current systematic review of published literature was to determine the difference in level of Streptococcus mutans in adults and children who chew sugar-free gum (SFG), compared with those who did not chew gum, who chewed a control gum or received alternatives such as probiotics or fluoride varnish.

Methods: Systematic review (PROSPERO registration No. CRD42018094676) of controlled trials with adult and child participants where chewing of SFG was the main intervention. Databases searched (1 Jan 1946 to 31 August 2020): MEDLINE, EMBASE, PsycINFO, Scopus, Web of Science, Allied and Complimentary Medicine Database, Cochrane Central Register of Controlled Trials (CENTRAL), Open Grey, PROSPERO and the Cochrane library of systematic reviews. 'Search terms included Medical Subject Headings, and free text to cover the following range of constructs: chewing gum, sugar free, oral health, caries, xerostomia, periodontal disease. Data extraction and Risk of Bias assessment was undertaken by three researchers using a modified version of the Cochrane RoB tool (version 1). Data synthesis was conducted using meta-analysis in STATA.
\end{abstract}

Results: Thirteen studies of SFG with micro-organisms as outcomes were identified. The use of SFG significantly reduced the load of Streptococcus mutans (effect size $-0.42 ; 95 \% \mathrm{Cl}-0.60$ to -0.25 ) compared to all controls. In seven of the 13 studies the confidence intervals of the effect size estimate included zero, suggesting no effect of the intervention. Twelve trials used xylitol gum only as the basis of the intervention; xylitol gum significantly reduced the load of Streptococcus mutans (effect size $-0.46 ; 95 \% \mathrm{Cl}-0.64$ to -0.28 ) in comparison to all controls. There was a moderate level of heterogeneity across the included studies. No adverse effects were recorded.

Conclusion: Chewing SFG reduces the load of Streptococcus mutans in the oral cavity in comparison to non-chewing controls. Considering the degree of variability in the effect and the moderate quality of the trials included, there is a need for future research exploring the use SFG as a preventive measure for reducing the cariogenic oral bacterial load.

Keywords: Prevention, Polyols, Xylitol, Children, Adults, Clinical trials, Oral bacteria, Streptococcus mutans

*Correspondence: melanie.nasseripour@kcl.ac.uk

Faculty of Dentistry, Oral and Craniofacial Sciences, King's College

London, Floor 26, Guy's Dental Hospital, Great Maze Pond, London SE1 9RT, UK

\section{Background}

The World Health Organisation (WHO) estimates the global burden of oral disease to affect half the world's population. Untreated dental caries in permanent teeth affects 2.4 billion people and caries of the primary dentition affects 532 million children [1]. The financial cost 
of oral healthcare is high averaging $5 \%$ of total health expenditure in high income countries and oral health needs are beyond capacity in most low- and middleincome countries [1].

The presence of oral micro-organisms is an accepted associated causative factor for the development of dental caries. Preventive measures could therefore target these micro-organisms, in addition to reducing sugar consumption. One implicated micro-organism is Streptococcus mutans (SM) (facultatively anaerobic, gram-positive), the presence of which is associated with driving the caries process $[2,3]$. The chewing of sugar-free gum (SFG) potentially provides a low cost adjunct to other caries preventive measures [4]. Its oral benefits relate to stimulating saliva, facilitating natural oral cavity clearance and delivering bacteriostatic ingredients such as xylitol and sorbitol to the oral biofilm [5, 6]. The United Kingdom (UK) Oral Health Foundation [7], the European Commission $[8,9]$, the European Food Safety Authority [10], and the World Dental Federation (FDI) [11], amongst other dental associations worldwide, have recognised these oral benefits.

This paper reports the findings of a systematic review of studies exploring the relationship between use of SFG and micro-organisms, specifically Streptococcus mutans, in the oral cavity, as part of a larger review of the role of sugar-free gum in relation to oral health. The research question addressed is, "In adults and children who chew sugar-free gum (SFG), compared with those who chew gums other than SFG (excluding sugared gum and gums with active ingredients), who do not chew gum or who use alternatives such as probiotics or fluoride varnish, what is the difference in level of oral micro-organisms, specifically Streptococcus mutans?".

\section{Methods}

\section{Protocol and registration}

The methodology for this systematic review was registered on PROSPERO (CRD42018094676).

\section{Inclusion criteria}

- Human participants: adults and children

- Primary research, published from 1 January 1946 to 31 August 2020

- Study designs: trials including randomised controlled trials (RCTs), crossover trials, pre-post trials, pre-post one arm trials, post-only trials and any design with a comparative arm. Crossover trials were required to have a minimum 'washout period' of 7 days between intervention arms.

- Full text available in English

\section{Exclusion criteria}

- Systematic or narrative reviews.

- Non-experimental studies.

- Laboratory-based studies.

- Non-adherence to experimental allocation. That is, any trial where the original participant allocation to intervention/control had been changed on any basis, such as self-reported behaviour, assessed level of use of active intervention.

- Conference abstracts.

- Incomplete datasets.

\section{Interventions}

Studies that had the chewing of SFG as the main intervention were included in the review. "Sugar" referred to monosaccharides (i.e. glucose, fructose, galactose) and disaccharides (i.e. sucrose, lactose, maltose) while polyols such as xylitol, sorbitol or malitol in gums satisfied the "sugar-free" criteria.

\section{Outcomes}

The outcomes reported related to Streptococcus mutans specifically:

- Streptococcus mutans count.

- Streptococcus mutans trends (decline).

- Streptococcus mutans mean \% change.

Reported adverse consequences (negative effects and harm) of SFG within the included studies, as well as acceptability and implementation methods leading to greater adherence, were collated. In addition, for each included study, data were extracted on potential effect modifiers.

\section{Information sources and search}

An information specialist (SDG) designed and conducted the search strategy, applying it to one database (OVID Medline) initially. Both Medical Subject Headings (MESH), and free text were used as the basis for search terms with combinations of chewing gum, sugar free, caries, xerostomia, periodontal disease (see Fig. 1). The detailed search was then adapted for all the relevant databases with appropriate modifications: Ovid MEDLINE, Ovid EMBASE, Ovid PsycINFO, Scopus, Web of Science, Allied and Complimentary Medicine Database (AMED), Cochrane Central Register of Controlled Trials (CENTRAL), Open Grey, as well as 


\section{Chewing Gum}

2 (chewing gum* or chewinggum*).mp. [mp=title, abstract, original title, name of substance word, subject heading word, keyword heading word, protocol supplementary concept word, rare disease supplementary concept word, unique identifier, synonyms]

31 or 2

4 (sugar free or sugar-free).mp. [mp=title, abstract, original title, name of substance word, subject heading word, keyword heading word, protocol supplementary concept word, rare disease supplementary concept word, unique identifier, synonyms]

5 exp Sweetening Agents/

6 (sweetening agent* or artificial sweetener* or nutritive sweetener* or non-nutritive sweetner* or xylitol or polyol or maltitol or sorbitol or sucralose or stevia or aspartame).mp. [mp=title, abstract, original title, name of substance word, subject heading word, keyword heading word, protocol supplementary concept word, rare disease supplementary concept word, unique identifier, synonyms]

75 or 6

$8 \quad 3$ and 4

$9 \quad 3$ and 7

10 Oral Health/

118 and 10

129 and 10

13 exp Dental Caries/

14 (dental caries or dental decay or tooth decay or tooth caries).mp. [mp=title, abstract, original title, name of substance word, subject heading word, keyword heading word, protocol supplementary concept word, rare disease supplementary concept word, unique identifier, synonyms]

$15 \quad 13$ or 14

168 and 15

179 and 15

18 exp Xerostomia/

19 (dry mouth or xerostomia or mouth dryness).mp. [mp=title, abstract, original title, name of substance word, subject heading word, keyword heading word, protocol supplementary concept word, rare disease supplementary concept word, unique identifier, synonyms]

$20 \quad 18$ or 19

218 and 20

229 and 20

23 exp Periodontal Diseases/

24 periodontal disease*.mp. or oral disease* or mucosal disease* [mp=title, abstract, original title, name of substance word, subject heading word, keyword heading word, protocol supplementary concept word, rare disease supplementary concept word, unique identifier, synonyms]

$25 \quad 23$ or 24

268 and 25

$27 \quad 9$ and 25

28 exp Smoking Cessation/

29 (smoking cessation or stop* smoking).mp. [mp=title, abstract, original title, name of substance word, subject heading word, keyword heading word, protocol supplementary concept word, rare disease supplementary concept word, unique identifier, synonyms]

$30 \quad 28$ or 29

$31 \quad 8$ and 30

329 and 30

33 exp Diet/

$34 \quad 8$ and 33

$35 \quad 9$ and 33

36 Sugars/

37 sugar*

$38 \quad 36$ or 37

$39 \quad 35$ not 38

$40 \quad 39$ and 8

$41 \quad 39$ and 9

Fig. 1 Search strategy for ovid medline, modified for other databases 
searching Prospero and the Cochrane library of systematic reviews.

\section{Study selection}

On the basis of the research question against the inclusion and exclusion criteria, an initial independent screening of titles and abstracts was done by two reviewers $(\mathrm{OA} / \mathrm{AB})$. All relevant full text relevant studies were checked for eligibility. Disagreements between reviewers was resolved by the input of a third reviewer (JTN). When further clarifications were required, attempts were made to contact study authors to confirm eligibility and ascertain methodological details. Following data extraction for full text review, articles were excluded if they did not meet the eligibility criteria (Fig. 2 and Additional file 1: Appendix). Fifteen papers were excluded because they were not available in English. Six of these manuscripts excluded on the basis of language related to caries outcome, whilst nine assessed plaque and salivary changes.

The references cited in the included studies were also reviewed to see if any additional papers could be identified meeting the initial inclusion criteria, resulting in seven further papers being included (JTN/MN).

Meta-analysis was undertaken using data recorded at baseline and at the end of each study. Where there was

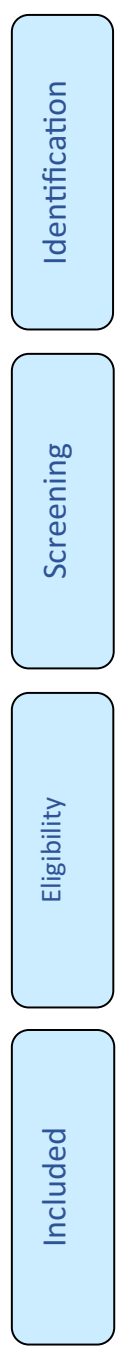

\section{Records identified through database searching} $(\mathrm{n}=509)$

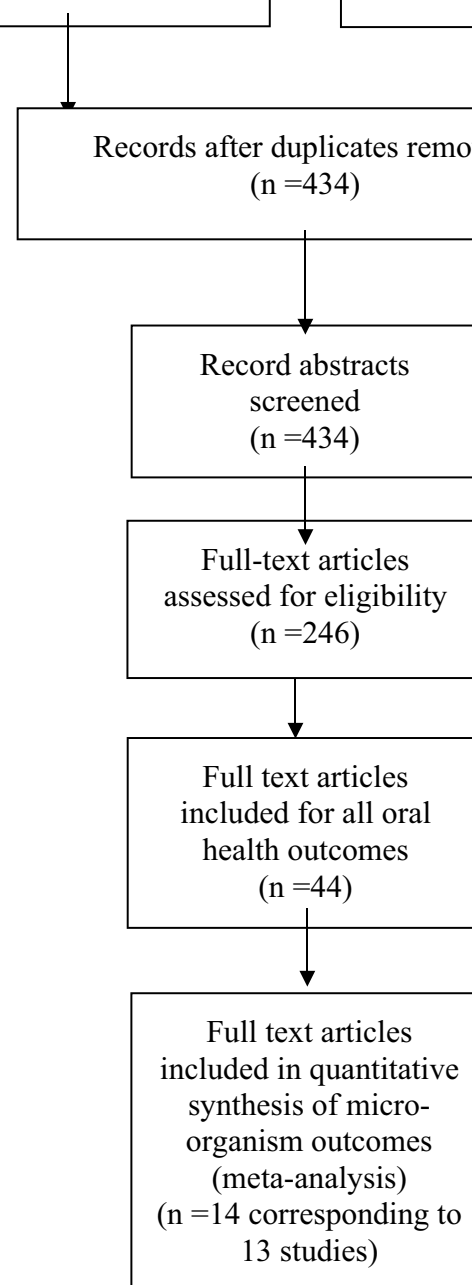

Additional records identified through other sources

(From SRs n $=13$, Ref Lists $=4$ ) 
more than one publication from a single study reporting outcomes at successive time points, only data relating to the final time point were used. If more than one SFG was investigated, these results were combined and compared to the control group. An analysis of xylitol-only gums was included as it was the most frequently adopted SFG tested and the investigators wished to determine whether any recommendations could be made for xylitol SFG specifically. Where the data for either the control or SFG arms were available at both baseline and at the end of the study, the paired data were re-created using the method outlined by Borenstein et al. [12]. The correlation between the baseline and the end of study data was assumed to be 0.95 for the control and 0.65 for the SFG group. These values were selected, following a process of discussion with researchers experienced in trials of oral health outcomes. In addition, parallel analyses were performed with a near perfect correlation (0.95) with no impact on the outcomes.

\section{Data collection process}

A pre-determined list of outcomes of interest was used to guide data extraction, developed and piloted by three investigators (OA/MN/JTN). Two investigators extracted the data from all studies, calling on the third in cases of disagreement. Twenty nine study authors were contacted, eight of whom provided additional data. Fourteen authors did not respond and a further seven responded but were unable to provide the information requested.

\section{Data items}

Data on Streptococcus mutans were recorded as mentioned above. In addition, for each included study, data were extracted on the potential effect modifiers such as:

- The intervention who delivered it, the setting, details of gum used e.g. ingredients and concentrations, recommended usage e.g. frequency of use, duration of use.

- Participant characteristics age, social class, sample size, diet, pre-existing conditions, risk of population, oral hygiene details.

- Relevant study details number of participants in each arm at baseline and included in analysis, number of withdrawals, follow up period, washout period, unit of randomisation, unit of analysis.

- Bibliographic details author(s), title, journal, country of origin, year of publication, trial design.

Differences were resolved through discussion and the input of a fourth investigator if necessary (AB). With studies published across multiple manuscripts, data were extracted just once but verified across all publications to ensure optimisation of data extraction.

\section{Risk of bias in individual studies}

Three reviewers (OA, JTN, MN) assessed all included studies independently across six domains: selection, performance, detection, attrition, reporting and 'other' biases using the Cochrane tool for assessing risk of bias (Modified version 1) [13]. If necessary, disagreements were resolved through discussion and with the input of a fourth investigator (AB) as required. Where a study design was not a randomised controlled trial, this was noted in the randomisation assessment in the "Risk of Bias" table (Table 2).

\section{Summary measures}

The effect size was calculated using the procedure metaeff in Stata v15.1 (StataCorp. 2017. Stata Statistical Software: Release 15. College Station, TX: StataCorp LLC). The metaan command in Stata v15.1 was then used to conduct a random effects maximum likelihood metaanalysis and draw forest plots, as well as to calculate the heterogeneity between studies.

\section{Risk of bias across studies}

Authors were contacted to clarify concerns regarding incomplete data, data in graphs or figures, pooled data, or incomplete information of key elements from the data extraction form. Missing information and/or additional clarification produced by authors was passed on to the statistician and if considered valid, these papers were included and data extraction completed.

\section{Changes to protocol following commencement of study}

Studies with apparently incomplete outcome data were excluded unless contact with the authors could ensure that the dataset was complete. Sensitivity analyses had been planned based on the risk of bias, but were not conducted as there was little variation across the studies for this variable. In the protocol, the analytical strategy stated that analyses would include all covariates (effect modifiers), but these were not included in the analyses reported here.

\section{Results}

A total of 14 full text articles, corresponding to 13 studies, with Streptococcus mutans levels as an outcome were included for analysis in this systematic review as summarised in Table 1. Figure 2 shows the PRISMA flow chart for identification of manuscripts included in this review. All 13 studies were included in the overall meta-analysis. Of these, 12 had used xylitol gum specifically as the basis of the intervention and these were considered in a 
Table 1 Summary characteristics of included studies

\begin{tabular}{|c|c|c|c|c|c|c|c|}
\hline Study citation & $\begin{array}{l}\text { Intervention } \\
\text { Daily frequency/ } \\
\text { time }\end{array}$ & amount/chew- & $\begin{array}{l}\text { Participant } \\
\text { characteristics }\end{array}$ & $\begin{array}{l}\text { Duration of } \\
\text { follow up }\end{array}$ & Study design & Control group & $\begin{array}{l}\text { Effect size } \\
(95 \% \mathrm{Cl})\end{array}$ \\
\hline Hoerman [16] & $\begin{array}{l}\text { Xylitol for } \\
10 \text { weeks }\end{array}$ & $\begin{array}{c}\text { Chewed } 5 \text { times a } \\
\text { day for } 10 \mathrm{~min}\end{array}$ & $\begin{array}{l}\mathrm{N}=30 \text { dental } \\
\text { students }\end{array}$ & 10 weeks & $\mathrm{RCT}$ & No gum & $\begin{array}{c}-0.31(-1.21, \\
0.59)\end{array}$ \\
\hline $\begin{array}{l}\text { Hildebrandt and } \\
\text { Sparks [17] }\end{array}$ & $\begin{array}{l}\text { Xylitol for } \\
3 \text { months }\end{array}$ & $\begin{array}{l}\text { Chewed } 3 \text { times } \\
\text { a day for } 5 \text { min } \\
\text { (after each } \\
\text { meal) }\end{array}$ & $N=151 ;$ adult & s 3 months & $\mathrm{RCT}$ & No gum & $\begin{array}{l}-0.70(-1.09 \\
-0.31)\end{array}$ \\
\hline $\begin{array}{l}\text { Thaweboon et al. } \\
\text { [18] }\end{array}$ & $\begin{array}{l}55 \% \text { xylitol and } \\
100 \% \text { xylitol for } \\
90 \text { days }\end{array}$ & $\begin{array}{c}\text { Chewed } 3 \text { times a } \\
\text { day for } 5 \mathrm{~min}\end{array}$ & $\begin{array}{l}\mathrm{N}=91 \text { schoolchi } \\
\text { dren aged } 10-12\end{array}$ & - 90 days & $\begin{array}{l}\text { Other-controlled } \\
\text { trial }\end{array}$ & No gum & $\begin{array}{l}-0.57(-1.00 \\
-0.13)\end{array}$ \\
\hline $\begin{array}{l}\text { Makinen et al. } \\
\text { [19] }\end{array}$ & $\begin{array}{l}\text { Xylitol and } \\
\text { d-glucitol for } \\
6 \text { months }\end{array}$ & $\begin{array}{l}\text { Chewed } 4 \text { times a } \\
\text { day for } 5 \mathrm{~min}\end{array}$ & $\begin{array}{l}\mathrm{N}=123 \text {, kinde } \\
\text { garten children }\end{array}$ & -6 months & $\mathrm{RCT}$ & No gum & $\begin{array}{l}-0.40(-0.84 \\
0.04)\end{array}$ \\
\hline Wang et al. [20] & $\begin{array}{l}\text { Sugar free gum } \\
\text { for } 14 \text { days }\end{array}$ & $\begin{array}{c}\text { Chewed } 5 \text { times a } \\
\text { day for } 10 \mathrm{~min}\end{array}$ & $\mathrm{~N}=40$ adult & s 2 weeks & $\mathrm{RCT}$ & No gum & $\begin{array}{l}-0.86(-1.48 \\
-0.24)\end{array}$ \\
\hline $\begin{array}{l}\text { Haresaku et al. } \\
\text { [21] }\end{array}$ & $\begin{array}{l}\text { Xylitol and } \\
\text { malatol for } \\
6 \text { months }\end{array}$ & $\begin{array}{l}\text { Chewed } 3 \text { times } \\
\text { a day for } 5 \text { min } \\
\text { (after each } \\
\text { meal) }\end{array}$ & $\mathrm{N}=128$ adult & s 6 months & $\begin{array}{l}\text { Patient prefer- } \\
\text { ence non- } \\
\text { randomised } \\
\text { trial }\end{array}$ & No gum & $\begin{array}{l}-0.10(-0.55 \\
0.34)\end{array}$ \\
\hline Calgar et al. [22] & Xylitol 21 days & $\begin{array}{c}\text { Chewed } 3 \text { times a } \\
\text { day for } 10 \mathrm{~min}\end{array}$ & $\begin{array}{l}\mathrm{N}=60 \text { adults (ag } \\
\text { range } 21-24 \text { years }\end{array}$ & 3 weeks & $\mathrm{RCT}$ & Placebo gum & $\begin{array}{l}-1.33(-2.18 \\
-0.48)\end{array}$ \\
\hline Campus et al. [23] & $\begin{array}{l}\text { Xylitol for } \\
9 \text { months }\end{array}$ & $\begin{array}{c}\text { Chewed } 5 \text { times a } \\
\text { day for } 5 \mathrm{~min}\end{array}$ & $\begin{array}{l}\mathrm{N}=176 \text { childre } \\
\text { aged } 7-9\end{array}$ & 9 months & $\mathrm{RCT}$ & Placebo gum & $\begin{array}{l}-0.01(-0.32, \\
0.31)\end{array}$ \\
\hline $\begin{array}{l}\text { Hildebrandt et al. } \\
\text { [24] }\end{array}$ & $\begin{array}{l}\text { Xylitol for } \\
3 \text { months }\end{array}$ & $\begin{array}{l}\text { Chewed } 3 \text { times a } \\
\text { day for } 5 \mathrm{~min}\end{array}$ & $N=105$ adult & s 3 months & $\mathrm{RCT}$ & No gum & $\begin{array}{l}-0.76(-1.23 \\
-0.28)\end{array}$ \\
\hline Seki et al. [25] & $\begin{array}{l}\text { Xylitol gum over } \\
3 \text { months }\end{array}$ & $\begin{array}{l}\text { Chewed } 4 \text { times/ } \\
\text { day (after } \\
\text { breakfast, } \\
\text { lunch, snacks, } \\
\text { and dinner) for } \\
5 \text { min }\end{array}$ & $\begin{array}{l}\mathrm{N}=161 \text { childre } \\
\text { aged } 3-4 \text { years }\end{array}$ & 9 months & $\mathrm{RCT}$ & Control gum & $\begin{array}{l}-0.33(-0.64 \\
-0.02)\end{array}$ \\
\hline $\begin{array}{l}\text { Alamoudi et al. } \\
\text { [26] and Hanno } \\
\text { et al. [27] }\end{array}$ & $\begin{array}{l}\text { Xylitol gum over } \\
3 \text { months }\end{array}$ & $\begin{array}{l}\text { Chewed } 3 \text { times a } \\
\text { day for } 5 \mathrm{~min}\end{array}$ & $\begin{array}{l}\mathrm{N}=34 \text { mother } \\
\text { child dyads }\end{array}$ & - 18 months & $\mathrm{RCT}$ & Fluoride varnish & $\begin{array}{l}-0.66(-1.65, \\
0.32)\end{array}$ \\
\hline $\begin{array}{l}\text { Al-Haboubi et al. } \\
\text { [28] }\end{array}$ & $\begin{array}{l}\text { Xylitol gum over } \\
6 \text { months }\end{array}$ & $\begin{array}{l}\text { Chewed } 2 \text { times } \\
\text { daily for } 15 \mathrm{~min}\end{array}$ & $\begin{array}{l}\mathrm{N}=186 \text { adult } \\
\text { aged over } 60 \text { year }\end{array}$ & s 6 months & $\mathrm{RCT}$ & No gum & $\begin{array}{l}-0.23(-0.56, \\
0.10)\end{array}$ \\
\hline $\begin{array}{l}\text { Ghassemi et al. } \\
\text { [29] }\end{array}$ & $\begin{array}{l}\text { Xylitol for } \\
4 \text { weeks }\end{array}$ & $\begin{array}{c}\text { Chewed } 3 \text { times a } \\
\text { day for } 5 \text { min }\end{array}$ & $\begin{array}{l}\qquad \mathrm{N}=50 \text { adult } \\
\text { (female university } \\
\text { students) }\end{array}$ & s 4 weeks & $\mathrm{RCT}$ & Probiotic & $\begin{array}{l}-0.18(-0.74 \\
0.37)\end{array}$ \\
\hline
\end{tabular}

separate meta-analysis. Studies lasted between 2 weeks and 18 months. Subjects were requested to chew from 2 to 5 times daily and for a length of 5-15 min. Though 6 out of the 13 trials asked participants to chew 3 times daily for $5 \mathrm{~min}$.

The analysis of the risk of bias within individual studies included in the review is summarised in Table 2. Of the 13 studies included in the review, 11 (84.6\%) were randomised controlled trials (RCTs), one (7.7\%) was a patient preference non-randomised trial and the remaining one $(7.7 \%)$ has been qualified as other since the methodology is unspecified. The randomisation of participants was unclear for five $(45.5 \%)$ of the RCTs and there was a high risk of bias for randomisation for one of the other study designs. Masking of participants was performed poorly for many of the trials and therefore was it was not possible to determine the level of selective reporting of outcomes in the manuscripts, which may reflect a lack of adherence with guidance on the reporting of clinical trials.

The results of the meta-analysis are presented in Fig. 3. The use of SFG significantly reduced the Streptococcus mutans load (effect size -0.42 ( $95 \%$ CI -0.60 to -0.25$)$ in comparison to all controls. There was moderate heterogeneity between studies $\left(\mathrm{I}^{2}=44 \%\right)$. Changing the correlation between the baseline and end of study data to 0.95 for the SFG group gave an effect size of -0.55 (95\% CI -0.80 to -0.30 ) and $\mathrm{I}^{2}=72.7 \%$. In seven of the 13 studies, the confidence intervals of the effect size estimate included zero, suggesting no effect of the intervention. 
Table 2 Summary of risk of bias of included studies

\begin{tabular}{|c|c|c|c|c|c|c|c|c|}
\hline & Study design & Randomisation & $\begin{array}{l}\text { Allocation } \\
\text { concealment }\end{array}$ & $\begin{array}{l}\text { Masking of } \\
\text { participants }\end{array}$ & $\begin{array}{l}\text { Masking } \\
\text { of } \\
\text { outcome } \\
\text { assessors }\end{array}$ & $\begin{array}{l}\text { Incomplete } \\
\text { outcome } \\
\text { reporting }\end{array}$ & $\begin{array}{l}\text { Selective } \\
\text { reporting }\end{array}$ & $\begin{array}{l}\text { Other } \\
\text { bias }\end{array}$ \\
\hline Hoerman [16] & $\mathrm{RCT}$ & Unclear & High risk & unclear & Unclear & Low risk & Low risk & Low risk \\
\hline $\begin{array}{l}\text { Hildebrandt and } \\
\text { Sparks [17] }\end{array}$ & $\mathrm{RCT}$ & Unclear & Unclear & Unclear & Low risk & Unclear & Unclear & Unclear \\
\hline $\begin{array}{l}\text { Thaweboon et al. } \\
\text { [18] }\end{array}$ & Other & Unclear [1] & Unclear & Unclear & Unclear & Unclear & Unclear & Unclear \\
\hline $\begin{array}{l}\text { Makinen et al. } \\
\text { [19] }\end{array}$ & $\mathrm{RCT}$ & Unclear & Unclear & Low risk & Low risk & High risk & Unclear & Unclear \\
\hline Wang et al. [20] & $\mathrm{RCT}$ & Low risk & Unclear & Unclear & Unclear & Low risk & Unclear & Unclear \\
\hline $\begin{array}{l}\text { Haresaku et al. } \\
\text { [20] }\end{array}$ & $\begin{array}{l}\text { Patient prefer- } \\
\text { ence non- } \\
\text { randomised } \\
\text { trial }\end{array}$ & High risk [2] & Unclear & Unclear & Low risk & High risk & Unclear & Unclear \\
\hline Calgar et al. [22] & $\mathrm{RCT}$ & Low risk & Unclear & Low risk & Low risk & Unclear & Unclear & Low risk \\
\hline Campus et al. [23] & $\mathrm{RCT}$ & Low risk & Low risk & Low risk & Low risk & Unclear & Unclear & Low risk \\
\hline $\begin{array}{l}\text { Hildebrandt et al. } \\
\text { [24] }\end{array}$ & $\mathrm{RCT}$ & Low risk & Unclear & High risk & Low risk & Low risk & Unclear & Unclear \\
\hline Seki et al. [25] & $\mathrm{RCT}$ & Low risk & Low risk & Low risk & Unclear & High risk & Unclear & High risk \\
\hline $\begin{array}{l}\text { Alamoudi et al. } \\
\text { [26] } \\
\text { Hanno et al. [27] }\end{array}$ & $\mathrm{RCT}$ & Unclear & High risk & High risk & Unclear & Unclear & Unclear & Unclear \\
\hline $\begin{array}{l}\text { Al-haboubi et al. } \\
\text { [28] }\end{array}$ & RCT & Low risk & Low risk & High risk & Low risk & Unclear & Unclear & Low risk \\
\hline $\begin{array}{l}\text { Ghassemi et al. } \\
\text { [29] }\end{array}$ & $\mathrm{RCT}$ & Unclear & Unclear & Low risk & Unclear & Low risk & Unclear & Unclear \\
\hline
\end{tabular}

Participants were divided into three groups which were balanced according to their S. mutans counts at baseline: one control group (no supervised gum use), and two xylitol groups (supervised 55\% and 100\% xylitol gum use). It is unclear whether they were or not randomised after stratification

Participants' preference for the flavour of gum was taken into account at allocation in an effort to enhance adherence to the chewing regimen

In the second meta-analysis of trials involving xylitol gum only, this gum significantly reduced Streptococcus mutans in comparison to all controls (effect size -0.46; $95 \% \mathrm{CI}-0.64$ to -0.28 ). Again, there was a moderate level of heterogeneity between studies with $\mathrm{I}^{2}=42.8 \%$. No adverse events were reported in any of the studies.

A sensitivity analysis was undertaken including only studies with adult participants. This made no significant difference to the effect sizes noted.

\section{Discussion}

This systematic review and meta-analysis confirm the Streptococcus mutans-reducing effect of xylitol-containing SFG and, as such, the potential for SFG to be considered as an adjunct to preventive oral health care regimes for dental caries management. Eleven of the 13 studies examined xylitol only. Xylitol competes with mono- and polysaccharides in the metabolic pathway but cannot be actively metabolised by Streptococcus mutans and therefore does not produce a decrease in salivary $\mathrm{pH}$ from lactic acid production. Xylitol also inhibits the attachment of Streptococcus mutans to the tooth surface [14]. The effect of chewing xylitol-containing SFG on Streptococcus mutans counts is potentially long-lasting, with evidence suggesting that it lowers the oral bacterial load for up to five years, after 2 years of use [15].

The main outcome analysed in these studies was the effect of SFG on levels of Streptococcus mutans with ten of the studies looking at the Streptococcus mutans count, one looking at average percentage change [20] and others at Streptococcus mutans decline [26, 30]. The overall effect size for all sugar-free gums $(-0.42)$ and for xylitolcontaining gums $(-0.46)$ compares favourably to other preventive interventions including oral health education [31] and supervised toothbrushing programmes alone [32]. No adverse events were reported but this may be related to absence of evidence, as few studies reported active attempts to gather data on possible adverse events.

The search strategy was wide ranging and comprehensive, including the review of the citations in all studies identified in the electronic searches. A strength of the studies reviewed is that the majority (all bar one) were randomised control trials, eight studies reporting on adults and five on children, with sample sizes of 30 


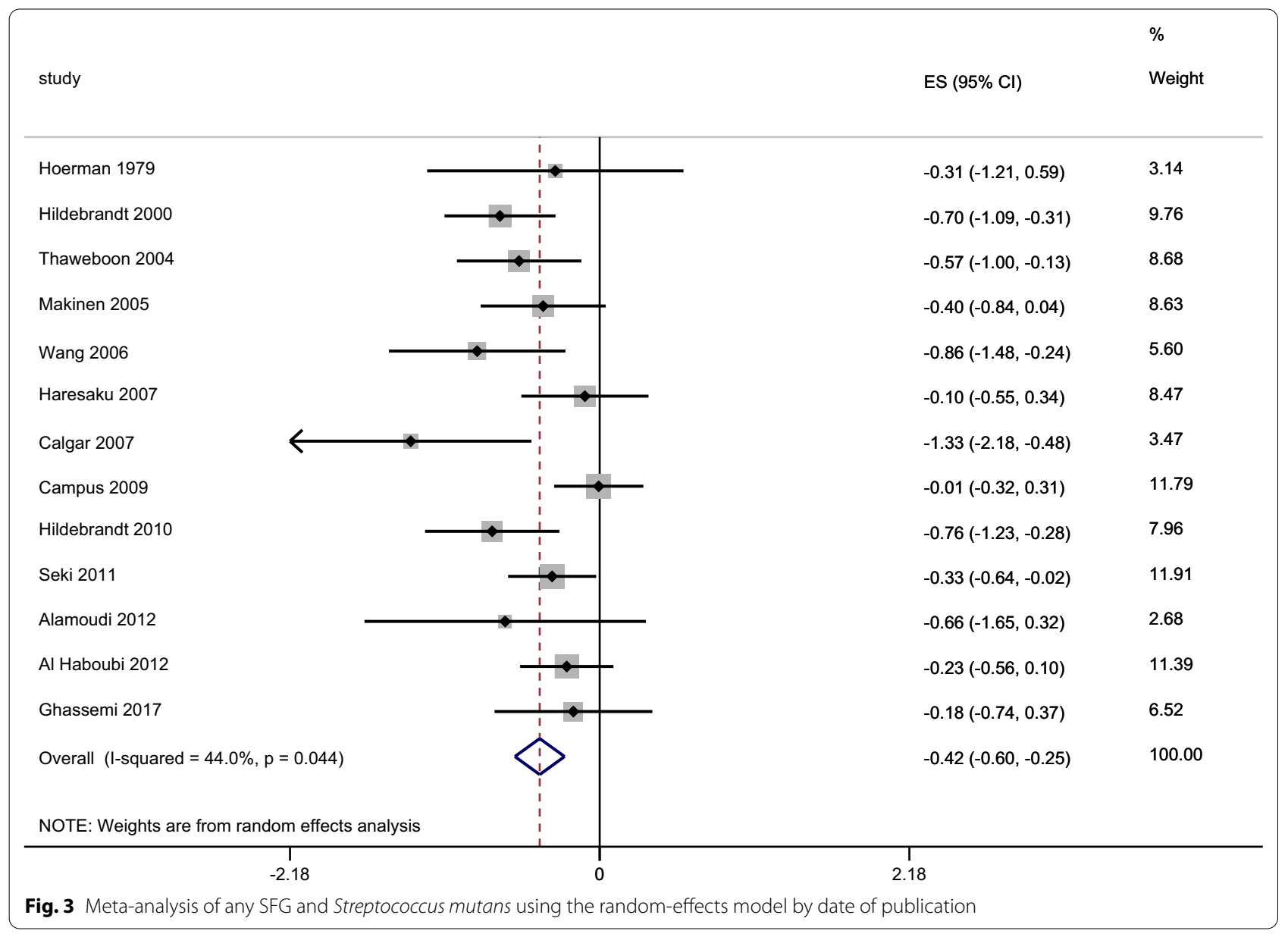

participants minimum and duration of follow up from four weeks to 18 months, which fits into accepted review/ recall protocols for caries management. It is important to acknowledge that the level of Streptococcus mutans is only one component of an individual's risk/susceptibility of dental caries. The clinical significance of the changes in levels of Streptococcus mutans identified in this study are yet to be determined, particularly on an individual basis where there are other risk factors present. However, the beneficial impact of chewing SFG on caries has been demonstrated and may be in part mediated through changes in levels of Streptococcus mutans [33]. As part of a preventive strategy, SFG has the advantage of being readily accessible. In addition, the use of other xylitolcontaining products is increasing, particularly in the dental setting with products such as toothpaste, rinses, and sprays including xylitol in their formulations.

Streptococcus mutans has been linked to certain cardiovascular pathologies as it is the most prevalent bacterial species detected in extirpated heart valve tissues (68.6\%), as well as in atheromatous plaques (74.1\%) [34]. Streptococcus sanguinis, closely related to Streptococcus mutans, has been linked to infective endocarditis [35]. Xylitol studies in rats have shown to increase collagen production in the skin, increase bone volume and bone mineral content and improve digestive health. These findings all need further investigation and in particular, more studies in humans [36-42]. Xylitol also does not appear to affect blood glucose and insulin levels [43-45]. Xylitol may also have antimicrobial effect on Candida albicans and can be used as an effective element in gums, toothpastes, and antimicrobial mouthwashes, especially in patients with candidiasis [46]. Therefore, the Streptococcus mutansreducing effect of xylitol-containing SFG is not only of value from an oral health perspective but also potentially for wider general health benefits. The recommendation would be to further research the effect of xylitol use on Streptococcus mutans counts in relation to the abovementioned general health-related outcomes. Any health benefits of using xylitol products must be considered in relation to the reported role of xylitol in gut dysbiosis and metabolic acidosis [45].

There was a high degree of heterogeneity among the studies in terms of the length of time, and the dosage of 
xylitol gum which formed the basis of the intervention, as well as the during of follow-up. Interestingly, the study which found little difference between the chewing group and the control (Campus 2009) had a long-expected duration of chewing ( 9 months) coupled with an equally long follow-up period (9 months). The lack of significant difference may be the result of the challenge of maintaining compliance with the intervention in children over this period. Studies with shorter intervention periods and shorter follow ups such as Wang et al. and Caglar et al., show large effect sizes and may reflect greater participant adherence. There are implications for the planning of interventions based on chewing gum-ensuring long term adherence may require specific support.

It is important to take into consideration the limitations of the current review. The search terms did not specifically include Streptococcus mutans. This was the result of the broad aim of the overarching registered systematic review protocol. This sought to focus on a range of oral health outcomes including levels of micro-organisms. It is possible that the exclusion of this specific search term may have meant that some relevant articles were not identified. The exclusion of articles not written in English may have led to bias. Hand-searching of relevant journals was not undertaken, but the authors did undertake a review of the references cited in the manuscripts identified for review, to the point where no new manuscripts were identified. There was a moderate level of heterogeneity in the trials in terms of the dosage and frequency of use of the SFGs, as well as in the length of follow-up, which makes it more difficult to draw conclusions concerning the ideal regime for the use of SFGs. However, the findings do suggest that regardless of variation in the manner of their use, there is a potential for reduction in Streptococcus mutans levels. Further research could focus on ascertaining the optimal duration and pattern of use of SFG; and, might explore the pharmacodynamics of the impact of xylitol on levels of Streptococcus mutans. From the present studies it is unclear the time point at which the maximal impact is reached. Further research might explore the pharmacodynamics of the impact of xylitol on levels of Streptococcus mutans.

The possibility of publication bias was not explored and there were insufficient data to conduct a sensitivity analysis to identify the variables contributing to the heterogeneity. From an analysis of the risk of bias, the quality of evidence was variable and there is a clear need for better designed trials which measures of participant adherence to the intervention and include reporting of adverse events, or their absence. Lastly, levels of Streptococcus mutans as measured in the studies included in this study are only one measure of the activity of the micro-organism in the oral cavity. Future research could seek to systematically review and synthesis the published literature appraising the impact of chewing SFGs on the qualitative determination of Streptococcus mutans activity, particularly amongst communities where caries risk is higher.

\section{Conclusion}

In conclusion there is evidence to support the use of sugar-free gum in the control of Streptococcus mutans counts, which in turn relate directly to caries progression in children and adults. Further research should be undertaken to assess the use SFG for the delivery of xylitol as a justifiable and achievable preventative measure in Dental Public Health.

\section{Abbreviations}

MN: Melanie Nasseripour; JTN: Jonathon Timothy Newton; OA: Oluwatunmise Awojobi; FW: Fiona Warburton; SDG: Sonya Di Giorgio; JEG: Jennifer Elizabeth Gallagher; AB: Avijit Banerjee; SFG: Sugar-free gum; WHO: World Health

Organisation; UK: United Kingdom; EFSA: European Food Safety Authority; FDI: Fédération Dentaire Internationale; ES: Standardised effect size; $\mathrm{Cl}$ : Confidence interval; RCT: Randomised control trial; MESH: Medical Subject Headings; Ovid: Object, view and interaction design; EMBASE: Excerpta Medica DataBASE; MEDLINE: Medical literature analysis and retrieval system online; PsycINFO: Psychological information database; AMED: Allied and Complimentary Medicine Database; CENTRAL: Cochrane Central Register of Controlled Trials; PICO: Population intervention comparison outcome; PF: Prevention factor; SMD: Standardised mean difference.

\section{Supplementary Information}

The online version contains supplementary material available at https://doi. org/10.1186/s12903-021-01517-z.

Additional file 1. Prisma Flow chart detail of the exclusions at full text review.

\section{Acknowledgements}

No acknowledgements.

\section{Authors' contributions}

MN, contributed to data acquisition, analysis, and interpretation, drafted and critically revised the manuscript; JTN, contributed to conception, design, data acquisition, analysis, and interpretation, and critically revised the manuscript; OA, contributed to data acquisition and analysis, critically revised the manuscript; FW, contributed to data acquisition and analysis, critically revised the manuscript; SDG, contributed to data acquisition, critically revised the manuscript; JEG, contributed to design, data analysis, and interpretation, and critically revised the manuscript; $A B$, contributed to conception, design, data acquisition, analysis, and interpretation, drafted and critically revised the manuscript. All authors gave final approval and agree to be accountable for all aspects of the work. All authors read and approved the final manuscript.

\section{Funding}

This investigator-led independent research financially sponsored by a grant from Mars Wrigley. They had NO role in the design of the study and collection, analysis, and interpretation of data and in writing the manuscript.

Availability of data and materials

All the data used in the systematic review presented in this publication is available upon request. 


\section{Declarations}

Ethics approval and consent to participate

Not applicable, this is review

\section{Consent for publication}

Not applicable.

\section{Competing interests}

The authors declare no potential conflicts of interest with respect to the authorship and/or publication of this article.

Received: 18 February 2020 Accepted: 15 March 2021

Published online: 29 April 2021

\section{References}

1. Bernabe E, Marcenes W, Hernandez CR, Bailey J, Abreu LG, Alipour V, Amini S, Arabloo J, Arefi Z, Arora A, Ayanore MA. Global, Regional, and national levels and trends in burden of oral conditions from 1990 to 2017: a systematic analysis for the global burden of disease 2017 study. J Dent Res. 2020;99(4):362-73.

2. Ryan KJ, Ray CG. Sherris medical microbiology. 4th ed. New York: McGraw Hill; 2003

3. Loesche WJ. Microbiology of dental decay and periodontal disease. In Baron S (eds). Medical microbiology, 4th edn. Galveston (TX): University of Texas Medical Branch at Galveston; 1996. Chapter 99. https://www. ncbi.nlm.nih.gov/books/NBK8259/. Accessed 12 Jan 2020.

4. Wessel SW, et al. Potential benefits of chewing gum for the delivery of oral therapeutics and its possible role in oral healthcare. Expert Opin Drug Deliv. 2016;13(10):1421-31.

5. Watt RG. Strategies and approaches in oral disease prevention and health promotion. Bull World Health Organ. 2005;83:711-8.

6. Dodds MW. The oral health benefits of chewing gum. J Ir Dent Assoc 2012;58(5):253-61.

7. Foundation $\mathrm{OH}$. Caring for teeth: sugar-free gum. 2018. https://www. dentalhealth.org/tell-me-about/topic/caring-for-teeth/sugar-free-chewi ng-gum. Accessed 12 Jan 2020.

8. Commission, E. Commission Regulation (EU) No 432/2012 of 16 May 2012 establishing a list of permitted health claims made on foods, other than those referring to the reduction of disease risk and to children's development and health Text with EEA relevance. 2012. http://eur-lex. europa.eu/legal-content/EN/ALL/?uri=CELEX:32012R0432. Accessed 12 Jan 2020

9. Commission, E. EU Register on nutrition and health claims. 2016. http:// ec.europa.eu/food/safety/labelling_nutrition/claims/register/public/? event=search. Accessed 12 Jan 2020

10. EFSA Panel on Dietetic Products, Nutrition and Allergies. Scientific Opinion on the substantiation of a health claim related to sugar free chewing gum and reduction of tooth demineralisation which reduces the risk of dental caries pursuant to Article 14 of Regulation (EC) No 1924/2006. EFSA J. 2010;8(10):1775

11. Federation, F.W.D. World Oral Health Day. 2015. https://www.fdiworldde ntal.org/press-releases/19-january-2015-its-time-to-smile-for-world-oralhealth-day-2015-and-take-care-with. Accessed 12 Jan 2020.

12. Borenstein MHL, Higgins JP, Rothstein HR. Introduction to meta-analysis. Hoboken: Wiley; 2011

13. Higgins JP, et al. The Cochrane Collaboration's tool for assessing risk of bias in randomised trials. BMJ. 2011;343:5928.

14. Al-Joburi W, Clark DC, Fisher R. A comparison of the effectiveness of two systems for the prevention of radiation caries. Clin Prev Dent. 1991;13(5):15-9.

15. American Dental Association Council on Scientific Affairs. Professionally applied topical fluoride evidence-based clinical recommendations. J Am Dent Assoc. 2006:137:1151-9.

16. Hoerman KC. Enumeration of Streptococcus mutans in human dental plaque after chewing gum sweetened with xylitol and sucrose. Pharmacol Ther Dent. 1979;4(1):11-9.
17. Hildebrandt GH, Sparks BS. Maintaining mutans streptococci suppression with xylitol chewing gum. J Am Dent Assoc. 2000;131(7):909-16.

18. Thaweboon $\mathrm{S}$, et al. The effect of xylitol chewing gum on mutans streptococci in saliva and dental plaque. Southeast Asian J Trop Med Public Health. 2004;35(4):1024-7.

19. Makinen KK, et al. Six-month polyol chewing-gum programme in kindergarten-age children: a feasibility study focusing on mutans streptococci and dental plaque. Int Dent J. 2005;55(2):81-8.

20. Wang YB, et al. Effects of xylitol in chewing gum on dental plaque and Streptococcus mutans. J Food Drug Anal. 2006;14(1):84-8.

21. Haresaku $S$, et al. Long-term effect of xylitol gum use on mutans streptococci in adults. Caries Res. 2007:41(3):198-203.

22. Caglar $\mathrm{E}$, et al. Effect of chewing gums containing xylitol or probiotic bacteria on salivary mutans streptococci and lactobacilli. Clin Oral Investig. 2007;11(4):425-9.

23. Campus $\mathrm{G}$, et al. Six months of daily high-dose xylitol in high-risk schoolchildren: a randomized clinical trial on plaque $\mathrm{pH}$ and salivary mutans streptococci. Caries Res. 2009:43(6):455-61.

24. Hildebrandt $\mathrm{G}$, et al. Oral mutans streptococci levels following use of a xylitol mouth rinse: a double-blind, randomized, controlled clinical trial. Spec Care Dent. 2010;30(2):53-8.

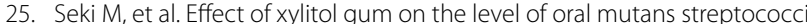
of preschoolers: block-randomised trial. Int Dent J. 2011;61(5):274-80.

26. Hanno AG, et al. Effect of xylitol on dental caries and salivary Streptococcus mutans levels among a group of mother-child pairs. J Clin Pediatr Dent. 2011;36(1):25-30.

27. Alamoudi NM, et al. Effects of xylitol on salivary mutans streptococcus, plaque level, and caries activity in a group of Saudi mother-child pairs. An 18-month clinical trial. Saudi Med J. 2012:33(2):186-92.

28. Al-Haboubi $M$, et al. The potential benefits of sugar-free chewing gum on the oral health and quality of life of older people living in the community: a randomized controlled trial. Commun Dent Oral Epidemiol. 2012;40(5):415-24

29. Ghasemi $E$, et al. Effect of probiotic yogurt and xylitol-containing chewing gums on salivary S mutans count. J Clin Pediatr Dent. 2017:41(4):257-63.

30. Alamoudi NM, et al. Impact of maternal xylitol consumption on mutans streptococci, plaque and caries levels in children. J Clin Pediatr Dent. 2012;37(2):163-6

31. Stein C, Santos NML, Hilgert JB, Hugo FN. Effectiveness of oral health education on oral hygiene and dental caries in schoolchildren: systematic review and meta-analysis. Community Dent Oral Epidemiol. 2018:46:30-7.

32. Dos Santos APP, De Oliveira BH, Nadanovsky P. A systematic review of the effects of supervised toothbrushing on caries incidence in children and adolescents. Int J Paediatr Dent. 2018;28:3-11.

33. Newton JT, Awojobi O, Nasseripour M, Warburton F, Di Giorgio S, Gallagher JE, Banerjee A. A systematic review and meta-analysis of the role of sugar-free chewing gum in dental caries. JDR Clin Trans Res. 2019. https:// doi.org/10.1177/2380084419887178

34. Nakano $\mathrm{K}$, Inaba $\mathrm{H}$, Nomura $\mathrm{R}$, Nemoto $\mathrm{H}$, Takeda M, Yoshioka H, Matsue $\mathrm{H}$, Takahashi T, Taniguchi K, Amano A, Ooshima T. Detection of cariogenic Streptococcus mutans in extirpated heart valve and atheromatous plaque specimens. J Clin Microbiol. 2006. https://doi.org/10.1128/JCM.00377-06.

35. Rao M, John G, Ganesh A, Jose J, Lalitha MK, John L. Infective endocarditis due to Streptococcus sanguis I occurring on a normal mitral valve. J Assoc Phys India. 1990;38(11):866-8.

36. Knuuttila ML, Kuoksa TH, Svanberg MJ, Mattila PT, Karjalainen KM, Kolehmainen E. Effects of dietary xylitol on collagen content and glycosylation in healthy and diabetic rats. Life Sci. 2000;67(3):283-90.

37. Mattila PT, Knuuttila ML, Svanberg MJ. Dietary xylitol supplementation prevents osteoporotic changes in streptozotocin-diabetic rats. Metabolism. 1998;47(5):578-83.

38. Mattila PT, Svanberg MJ, Pökkä P, Knuuttila ML. Dietary xylitol protects against weakening of bone biomechanical properties in ovariectomized rats. J Nutr. 1998;128(10):1811-4.

39. Mattila PT, Svanberg MJ, Knuuttila ML. Increased bone volume and bone mineral content in xylitol-fed aged rats. Gerontology. 2001;47(6):300-5.

40. Mattila PT, Svanberg MJ, Jämsä T, Knuuttila ML. Improved bone biomechanical properties in xylitol-fed aged rats. Metabolism. 2002:51(1):92-6. 
41. Mattila PT, Pelkonen P, Knuuttila ML. Effects of a long-term dietary xylito supplementation on collagen content and fluorescence of the skin in aged rats. Gerontology. 2005;51(3):166

42. Salminen S, Salminen E, Koivistoinen P, Bridges J, Marks V. Gut microflora interactions with xylitol in the mouse, rat and man. Food Chem Toxicol. 1985;23(11):985-90.

43. Hassinger W, Sauer G, Cordes U, Krause U, Beyer J, Baessler KH. The effects of equal caloric amounts of xylitol, sucrose and starch on insulin requirements and blood glucose levels in insulin-dependent diabetics. Diabetologia. 1981;21(1):37-40.

44. Nguyen NU, Dumoulin G, Henriet MT, Berthelay S, Regnard J. Carbohydrate metabolism and urinary excretion of calcium and oxalate after ingestion of polyol sweeteners. J Clin Endocrinol Metab. 1993;77(2):388-92.

45. Janket S, Benwait J, Isaac P, Ackerson LK, Meurman JH. Oral and systemic effects of xylitol consumption. Caries Res. 2019;53:91-501.

46. Talattof Z, Azad A, Zahed M, Shahradnia N. Antifungal activity of xylitol against Candida albicans: an in vitro study. J Contemp Dent Pract. 2018;19(2):125-9.

\section{Publisher's Note}

Springer Nature remains neutral with regard to jurisdictional claims in published maps and institutional affiliations.
Ready to submit your research? Choose BMC and benefit from:

- fast, convenient online submission

- thorough peer review by experienced researchers in your field

- rapid publication on acceptance

- support for research data, including large and complex data types

- gold Open Access which fosters wider collaboration and increased citations

- maximum visibility for your research: over 100M website views per year

At BMC, research is always in progress.

Learn more biomedcentral.com/submissions 